\title{
The direct and indirect effects of nitrogen shortage on photosynthesis and transpiration in maize and sunflower
}

\section{J. Goudriaan ${ }^{1}$ and $H$. van Keulen ${ }^{2}$}

1 Department of Theoretical Production Ecology, Agricultural University, Wageningen, the Netherlands

2 Centre for Agrobiological Research (CABO), Wageningen, the Netherlands

Accepted: 15 May 1979

Key words: photosynthesis, transpiration, stomatal resistance, water use efficiency, nitrogen nutrition

\section{Summary}

Experiments were carried out to investigate the effect of nitrogen shortage in the leaf tissue on stomatal behaviour. The results show that in maize a linear relation exists between the rate of net $\mathrm{CO}_{2}$ assimilation and the conductance for water vapour, independently of the nitrogen status of the tissue. In sunflower a similar relation exists although the evidence is less conclusive. It is concluded that stomatal behaviour cannot explain differences in water use efficiency between plants, growing at different levels of nitrogen.

\section{Introduction}

Numerous experiments have been carried out to investigate the relation between dry matter production and water use. It has been shown that in many situations there is a constant ratio between the two values for a given plant species under well defined environmental conditions (de Wit, 1958). However, too often exceptions are encountered that are difficult to explain physiologically.

One way to obtain insight in the influence of external factors on stomatal behaviour and on the ratio between photosynthesis and transpiration is simultaneous measurement of transpiration and $\mathrm{CO}_{2}$ assimilation of individual leaves. The results presented in a previous paper (Goudriaan \& van Laar, 1978) showed that in maize and bean plants, functioning under presumably optimum conditions, the rate of net photosynthesis and the leaf conductance for water vapour are proportional to each other. Since this proportionality was maintained at non-saturating light intensities, it was concluded that leaf resistance was not the limiting factor for $\mathrm{CO}_{2}$ assimilation. The stomata did close, however, over some range in response to increase in external $\mathrm{CO}_{2}$ concentration, so that regulation by the $\mathrm{CO}_{2}$ concentration in the sub- 
stomatal cavity seems the most likely explanation for the observed proportionality. In maize the mechanism maintains internal $\mathrm{CO}_{2}$ concentrations around $120 \mu \mathrm{l} / \mathrm{l}$, in bean (Phaseolus) on the other hand around $220 \mu \mathrm{l} / \mathrm{l}$. In sunflower the regulation appeared to be absent, leading to higher and more variable values for the internal $\mathrm{CO}_{2}$ concentration. Further experiments carried out since then have shown, however, that the regulatory mechanism can be present to a greater or lesser extent in the same plant species, depending on (as yet) unknown external or internal conditions. Absence of regulation leads to higher transpiration losses in plant stands at the same photosynthetic performance and hence to lower values of water use efficiency. This phenomenon may explain part of the so far unexplicable values of water use efficiency.

Field and container experiments indicate that nutrient shortage in general causes deterioration of the water use efficiency (Lof, 1976; Nielsen, 1963), a phenomenon that was treated in some detail by Viets (1962). It was speculated therefore whether nitrogen shortage could bring about differences in stomatal behaviour, that could account for the observed decrease in water use efficiency. This paper describes the results of experiments, carried out to investigate the influence of nitrogen shortage on photosynthesis and transpiration of individual leaves.

\section{Materials and methods}

Seeds of maize (Zea mays, cv. LG11) and sunflower (Helianthus annuus, cv. Fransol) were germinated on perlite and one-week old seedlings were transferred to pots, filled with a Hoagland nutrient solution of half strength, with iron added as ferric sodium-EDTA. The plants were grown in a growth chamber at a temperature of $20^{\circ} \mathrm{C}$, a light intensity of $60 \mathrm{~W} \mathrm{~m}$ m $^{-2}$ at plant height and a relative humidity around $70 \%$.

At the age of three weeks, half of the maize plants were transferred to nutrient solutions in which the $\mathrm{NO}_{3}^{-}$was replaced by $\mathrm{Cl}^{-}$, while the remainder, serving as control, continued to grow on the normal solution. After one week on the nitrogendepleted solution, the plants showed visible signs of nitrogen shortage: light green leaves, browning tips in old ones. At that moment the measurements started.

The sunflower plants were grown on the half-Hoagland solution for two weeks, after which they were divided into four groups, growing on solutions in which 0 (control), 50, 80 and $90 \%$ of the nitrate was replaced by chloride respectively. The measurements started three weeks later. The nutrient solutions were replaced twice a week.

The measurements were carried out on leaves attached to the plants, at a temperature of $25^{\circ} \mathrm{C}$, an irradiance up to $\pm 400 \mathrm{~W} \mathrm{~m}^{-2}(400-700 \mathrm{~nm})$ and, unless indicated otherwise, a $\mathrm{CO}_{2}$ concentration of $280 \mu \mathrm{l} / 1$.

\section{Results and discussion}

Maize

The photosynthesis-light response curve of the maize leaves, averaged over 20 


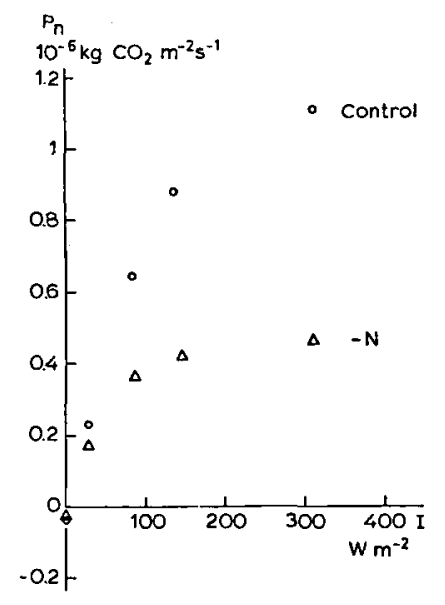

Fig. 1. The relation between the incident light intensity (I) and the net rate of $\mathrm{CO}_{2}$ assimilation $\left(\mathrm{P}_{\mathrm{n}}\right)$ for maize plants grown with and without nitrogen. $\mathrm{CO}_{2}$ concentration 280 $\mu 1 / 1$.

plants, of both the control and the nitrogen stressed treatment is given in Fig. 1. These curves can be described by:

$$
\mathrm{P}_{\mathrm{n}}=\left(\mathrm{P}_{\mathrm{m}}+\mathrm{R}\right) \times\left(1 \text { - }-\exp \left(\varepsilon \mathrm{I} /\left(\mathrm{P}_{\mathrm{m}}+\mathrm{R}\right)\right)\right)-\mathrm{R}
$$

in which $\mathrm{I}=$ absorbed visible radiation $\left(\mathrm{W} \mathrm{m}^{-2}\right)$

$$
\begin{aligned}
& \mathrm{P}_{\mathrm{m}}=\text { the light saturated net assimilation rate }\left(\mathrm{kg}\left(\mathrm{CO}_{2}\right) \mathrm{m}^{-2} \text { (leaf) } \mathrm{s}^{-1}\right) \\
& \mathrm{R}=\text { dark respiration rate }\left(\mathrm{kg}\left(\mathrm{CO}_{2}\right) \mathrm{m}^{-2}(\text { leaf }) \mathrm{s}^{-1}\right) \\
& \varepsilon=\text { light use efficiency }\left(\mathrm{kg}\left(\mathrm{CO}_{2}\right) \mathrm{J}^{-1}\right)
\end{aligned}
$$

The numerical values of these parameters are given in Table 1a, which shows that nitrogen shortage reduced $P_{m}$ to less than half the value of the control and the light use efficiency to about $80 \%$. (Unfortunately the nitrogen concentration in the tissue was not determined, so that its nitrogen status can only be described in qualitative terms.) There is surprisingly little difference in the dark respiration rate between the two treatments. That may, however, be understandable when it is taken into account that the plants in the growth chamber are operating at a very low energy level, so that the actual level of 'activity', which accounts for about $70 \%$ of the respiratory requirements (de Wit et al., 1978) does not differ too much between the control and the nitrogen deficient plants. It may therefore not be concluded from these observations that, when the plants are operating at higher energy levels, a greater proportion of the fixed energy is lost from the nitrogen-stressed plants.

To investigate whether the observed decline in photosynthetic performance of the nitrogen-deprived plants was an indirect effect, caused by the accumulation of assimilates in the leaves as a result of growth inhibition, the two treatment groups were further subdivided. One group was measured directly after a 28 -hour dark period, the other one after a 16-hour period in light at an intensity of $300 \mathrm{~W} \mathrm{~m}^{-2}$ visible. Two main effects could be distinguished. The dark respiration rate was considerably higher after the light period for both the control (from $18 \times 10^{-9}$ to $\left.35.5 \times 10^{-8} \mathrm{~kg}\left(\mathrm{CO}_{2}\right) \mathrm{m}^{-2} \mathrm{~s}^{-1}\right)$, and the nitrogen-stressed plants (from $17.5 \times 10^{-8}$ to $\left.27 \times 10^{-} \mathrm{kg}\left(\mathrm{CO}_{2}\right) \mathrm{m}^{-2} \mathrm{~s}^{-1}\right)$. There was also a significant difference in the specific 
Table 1. The maximum rate of photosynthesis $\left(\mathbf{P}_{\mathrm{m}}\right)$, the light use efficiency $(\varepsilon)$ and the rate of dark respiration (R) for maize and sunflower leaves at different levels of $\mathrm{N}$ supply and, for sunflower, different concentrations of $\mathrm{CO}_{2}$ external.

\begin{tabular}{|c|c|c|c|c|c|c|c|}
\hline & \multicolumn{2}{|c|}{ Maize } & \multicolumn{5}{|l|}{ Sunflower } \\
\hline & \multirow{2}{*}{$\begin{array}{l}\text { con- } \\
\text { trol } \\
280 \\
\mu 1 / 1\end{array}$} & \multirow{2}{*}{$\begin{array}{l}-\mathrm{N} \\
280 \\
\mu 1 / 1\end{array}$} & \multirow{2}{*}{$\begin{array}{ll}\mathrm{N} 1 \\
280 & 480 \\
\mu \mathrm{l} / 1 & \mu \mathrm{l} / 1\end{array}$} & \multirow{2}{*}{$\begin{array}{ll}\mathrm{N} & 1 / 2 \\
280 & 480 \\
\mu 1 / 1 & \mu 1 / 1\end{array}$} & \multirow{2}{*}{$\begin{array}{ll}\mathrm{N} & 1 / 5 \\
280 & 480 \\
\mu 1 / 1 & \mu 1 / 1\end{array}$} & \multicolumn{2}{|c|}{ N $1 / 10$} \\
\hline & & & & & & $\begin{array}{l}280 \\
\mu 1 / 1\end{array}$ & $\begin{array}{l}480 \\
\mu 1 / 1\end{array}$ \\
\hline $\begin{array}{l}\mathrm{P}_{\mathrm{m}}\left(10^{-6} \mathrm{~kg}\left(\mathrm{CO}_{2}\right) \mathrm{m}^{-2} \mathrm{~s}^{-1}\right) \\
\varepsilon\left(10^{-9} \mathrm{~kg}\left(\mathrm{CO}_{2}\right) \mathrm{J}^{-1}\right)\end{array}$ & $\begin{array}{l}1.16 \\
11.9\end{array}$ & $\begin{array}{l}0.47 \\
9.2\end{array}$ & $\begin{array}{lc}0.69 & 1.11 \\
9.7 & 14.2\end{array}$ & $\begin{array}{lc}0.44 & 0.58 \\
8.6 & 10.6\end{array}$ & $\begin{array}{lc}0.49 & 0.81 \\
8.6 & 11.1\end{array}$ & $\begin{array}{l}0.42 \\
8.6\end{array}$ & $\begin{array}{l}0.64 \\
9.2\end{array}$ \\
\hline $\mathrm{R}\left(10^{-6} \mathrm{~kg}\left(\mathrm{CO}_{2}\right) \mathrm{m}^{2-} \mathrm{s}-1\right)$ & 0.035 & 0.027 & 0.032 & 0.030 & 0.036 & 0.0 & \\
\hline
\end{tabular}

leaf dry weight of the nitrogen-stressed plants after the dark $\left(27 \times 10^{-3} \mathrm{~kg} \mathrm{~m}^{-2}\right)$ and after the light period $\left(33 \times 10^{-3} \mathrm{~kg} \mathrm{~m}^{-2}\right)$, whereas in the control group it was in both cases the same $\left(31 \times 10^{-3} \mathrm{~kg} \mathrm{~m}^{-2}\right)$. When the respiration rates are calculated on a dry weight basis, the values amount to $0.58 \times 10^{6} \mathrm{~kg}\left(\mathrm{CO}_{2}\right) \mathrm{kg}(\mathrm{dm})^{-1} \mathrm{~s}^{-1}$ and $1.15 \times 10^{-6}$ for the control plants and to $0.65 \times 10^{-6}$ and $0.82 \times 10^{-6}$ for the nitrogen-stressed plants after dark and after light respectively. These observations indicate considerable assimilate accumulation in the leaves of the nitrogen-stressed plants, and fast export from the leaves of the non-stressed ones, the higher respiration rate being partly the result of higher photosynthetic activity, partly associated with transportation cost. Comparison of the respiration rates, measured after the

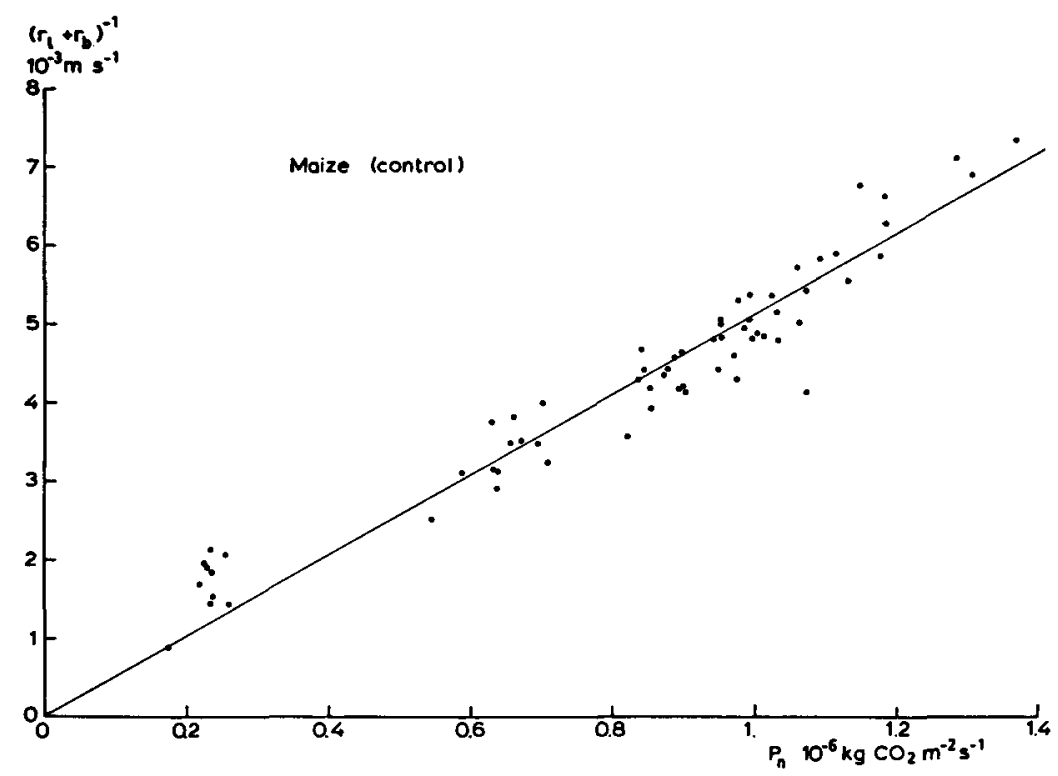

Fig. 2. The relation between the net rate of $\mathrm{CO}_{2}$ assimilation $\left(\mathrm{P}_{\mathrm{n}}\right)$ and the total conductance $\left(\left(r_{1}+r_{b}\right)-1\right)$ for water vapour for leaves of maize plants well supplied with nitrogen. $\Delta \mathrm{CO}_{2}=166 \mu \mathrm{l} / \mathrm{l}$. 


\section{EFFECTS OF NITROGEN SHORTAGE ON MAIZE AND SUNFLOWER}

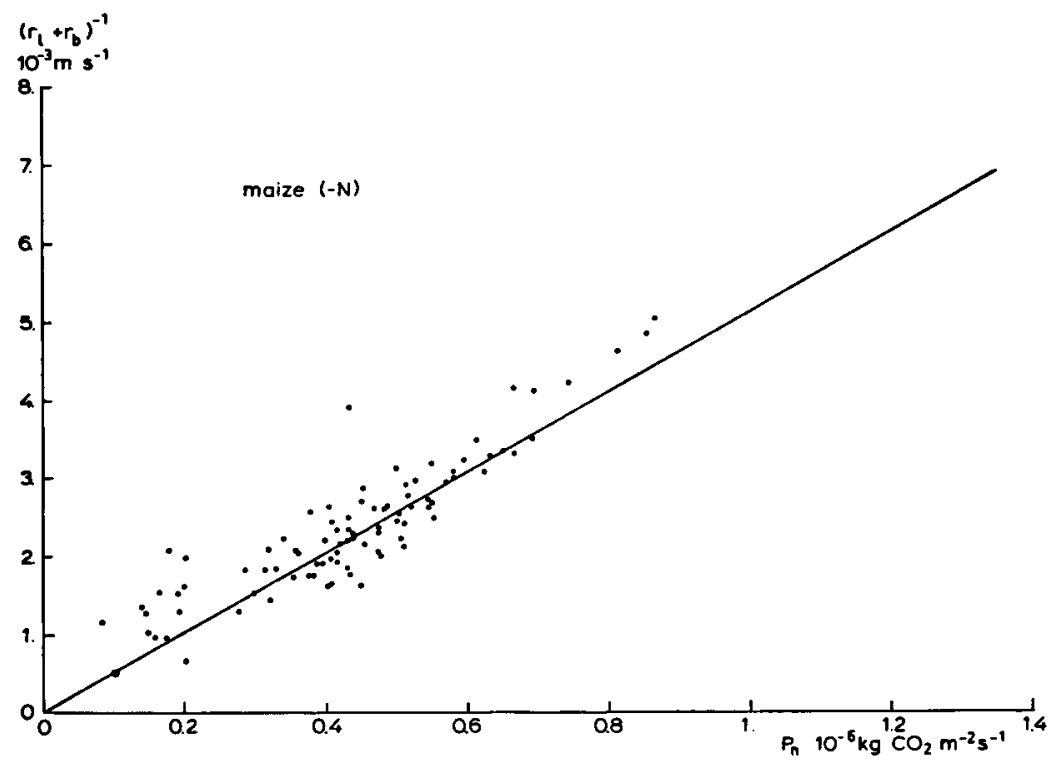

Fig. 3. The relation between the net rate of $\mathrm{CO}_{2}$ assimilation $\left(\mathrm{P}_{n}\right)$ and the total conductance for water vapour $\left(\left(r_{1}+r_{b}\right)-1\right)$ for leaves of maize plants growing at sub-optimum nitrogen nutrition.

light period, with the $\mathrm{P}_{\mathrm{m}}$ values in Table 1 could suggest a somewhat higher respiratory loss per unit of assimilation in the nitrogen-stressed plants, but the evidence is not very convincing.

There was, however, no difference in the maximum rate of photosynthesis nor in light use efficiency between the stressed plants that had been in the dark and those that had been in the light. The reduction in photosynthetic performance therefore seems not to be associated with assimilate accumulation in the leaves.

Since the water use efficiency is a main point of interest, the relation between the conductance for water vapour (the inverse of the sum of leaf resistance and boundary layer resistance) and the net rate of $\mathrm{CO}_{2}$ assimilation was determined. The data points for the control group, measured at various light intensities, are given in Fig. 2. A linear relationship seems a reasonable approximation, indicating an almost constant $\mathrm{CO}_{2}$ concentration in the substomatal cavity. The eye-fitted straight line, forced through the origin represents a difference between external and internal $\mathrm{CO}_{2}$ concentration of $166 \mu \mathrm{l} / \mathrm{l}$, so that the internal concentration was maintained around $110-120 \mu \mathrm{l} / \mathrm{l}$. This agrees very well with earlier observations (Goudriaan \& van Laar, 1978). The results of the measurements at the lowest light intensity ( $27 \mathrm{~W} \mathrm{~m}^{-2}$ visible, incident), however, are all situated above the eye-fitted line, indicating disproportionally higher conductance values and hence higher internal $\mathrm{CO}_{2}$ concentrations, amounting to ca. $160 \mu \mathrm{l} / \mathrm{l}$, indicating that the regulatory mechanism is not operating perfectly over the complete range of photosynthesis rates. 

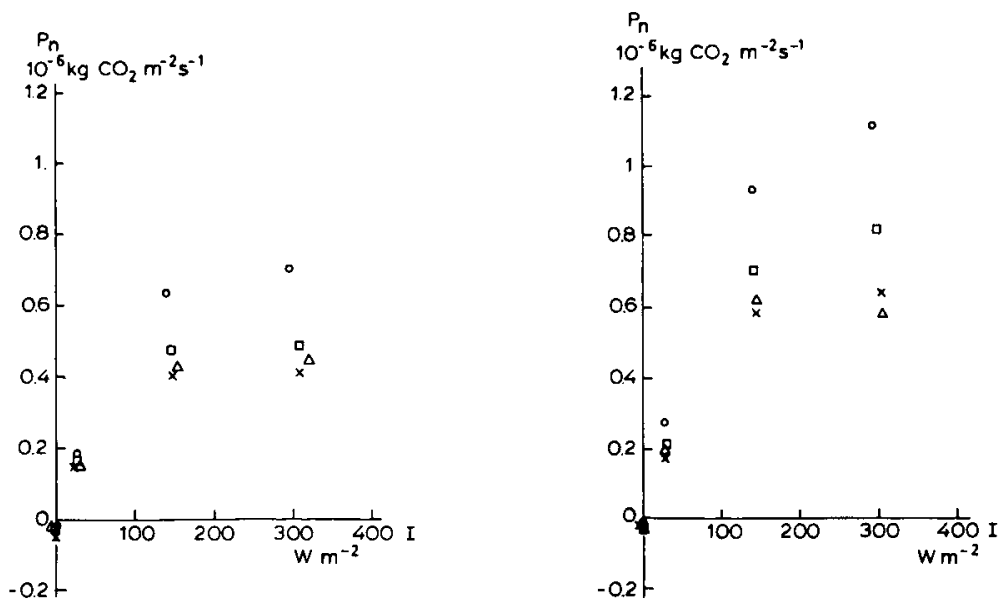

Fig. 4. The relation between incident light intensity (I) and the rate of net $\mathrm{CO}_{2}$ assimilation $\left(P_{n}\right)$ for leaves of sunflower plants, grown in solutions where $0(O), 50(\triangle), 80(\square)$ or $90(\times) \%$ of the nitrate had been replaced by chloride, measured at an external $\mathrm{CO}_{2}$ concentration of $280 \mu \mathrm{l} / 1$ (left) and $480 \mu \mathrm{l} / 1$ (right).

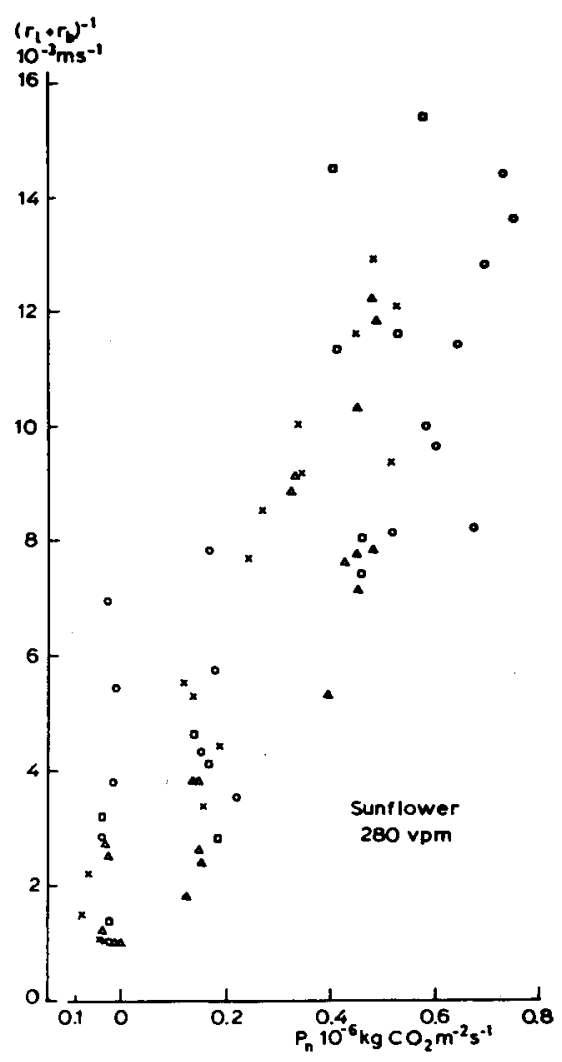

Fig. 5. The relation between the net rate of $\mathrm{CO}_{2}$ assimilation $\left(\mathrm{P}_{\mathrm{n}}\right)$ and the total conductance for water vapour $\left.\left(r_{1}+r_{b}\right)^{-1}\right)$ for leaves of sunflower plants, grown in solutions where $0(O), 50(\triangle), 80(\square)$ or $90(X) \%$ of the nitrate had been replaced by chloride, and measured at an external $\mathrm{CO}_{2}$ concentration of $280 \mu \mathrm{l} / \mathrm{l}$. 


\section{EFFECTS OF NITROGEN SHORTAGE ON MAIZE AND SUNFLOWER}

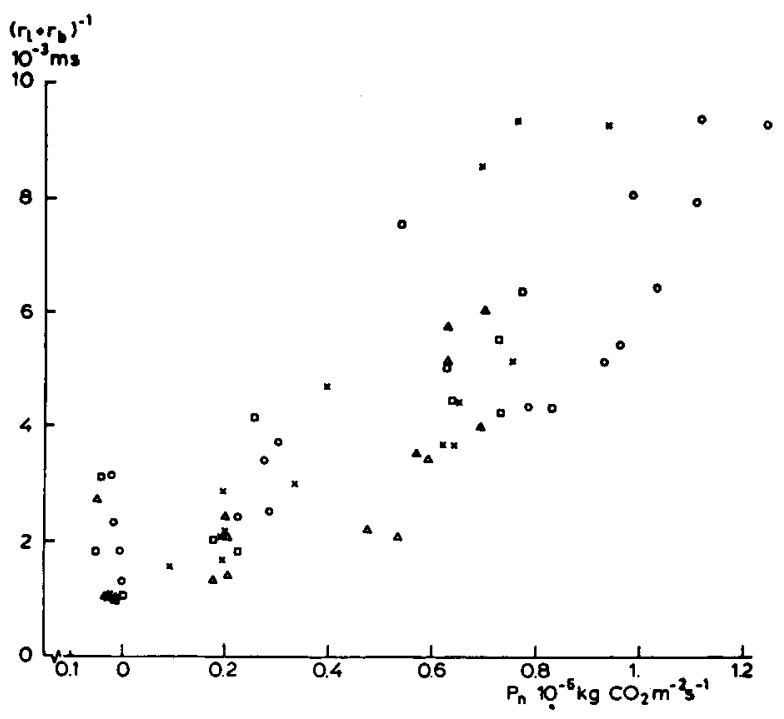

Fig. 6. The relation between the net rate of $\mathrm{CO}_{2}$ assimilation $\left(\mathrm{P}_{\mathrm{n}}\right)$ and the total conductance for water vapour $\left(r_{1}+r_{b}\right)^{-1}$ ) for leaves of sunflower plants, grown in solutions where $0(O)$, $50(\triangle), 80(\square)$ or $90(\times) \%$ of the nitrate had been replaced by chloride, and measured at an external $\mathrm{CO}_{2}$ concentration of $480 \mu \mathrm{l} / \mathrm{l}$.

The data points for the nitrogen-deficient plants are give in Fig. 3. Surprisingly, the points are arranged in a similar fashion as in Fig. 2 around the same straight line, which has been repeated here for comparison. These results indicate that as far as stomatal regulation is involved, only a small effect of nitrogen stress on water use efficiency may be expected in maize plants.

\section{Sunflower}

The photosynthesis-light response curves for sunflower plants grown at different levels of $\mathrm{N}$ supply, measured at external $\mathrm{CO}_{2}$ concentrations of 280 and $480 \mu \mathrm{l} / \mathrm{l}$ respectively, are given in Fig. 4. Net $\mathrm{CO}_{2}$ assimilation is positively related to both the level of $\mathrm{N}$ in the nutrient solution and the $\mathrm{CO}_{2}$ concentration in the external air. This holds for the maximum rate, $\mathrm{P}_{\mathrm{m}}$, as well as for the light use efficiency, $\varepsilon$ (Table 1b).

In Fig. 5 and 6 the relation between conductance for water vapour and net $\mathrm{CO}_{2}$ assimilation is given for the two levels of $\mathrm{CO}_{2}$ in the external air. In both cases there is a positive correlation between the variables, which, when expressed in terms of the difference in $\mathrm{CO}_{2}$ concentration between the outside air and the substomatal cavity, corresponds to values of 40 and $80 \mu \mathrm{l} / \mathrm{l}$ for the low and high external concentration respectively. Hence in this case the stomata of the plants did respond to some extent to the increased $\mathrm{CO}_{2}$ level in the external air, contrary to earlier observations (Goudriaan \& van Laar, 1978). Lower levels of nitrogen in the solution, and presumably therefore in the plant tissue, lead to decreased rates 
of photosynthesis as well as transpiration, but due to the scatter in the individual observations, the conclusion of an invariant conductance/assimilation ratio cannot be drawn with certainty.

\section{Conclusions}

The results presented in this paper indicate that for maize and sunflower very little difference in water use efficiency at different levels of nitrogen nutrition may be expected, on basis of assimilation and transpiration of individual leaves. There is some indication that at lower $\mathrm{N}$ levels a proportionally larger part of the assimilated carbon is lost by respiration, which could be associated with breakdown and transport of nitrogeneous compounds.

Observations showing deterioration of water use efficiency for whole plants or crops under conditions of $\mathbf{N}$ shortage may thus have to be attributed to differences in the distribution pattern of the assimilates, notably a larger share for the underground plants parts. Measurement of the carbon balance for different organs over a longer time period could elucidate this hypothesis.

\section{References}

Goudriaan, J. \& H. H. van Laar, 1978. Relations between leaf resistance, $\mathrm{CO}_{2}$-concentration and $\mathrm{CO}_{2}$-assimilation in maize, beans, lalang grass and sunflower. Photosynthetica 12: 241249.

Lof, H., 1976. Water use efficiency and competition between arid zone annuals, especially the grasses Phalaris minor and Hordeum murinum. Agric. Res. Rep. (Versl. landbouwk. Onderz.) 853, Pudoc, Wageningen.

Nielsen, B. F., 1963. Plant production, transpiration ratio and nutrient ratios as influenced by interactions between water and nitrogen. Thesis, Royal Veterinary \& Agricultural College, Copenhagen.

Viets Jr, F. G., 1962. Fertilizers and the efficient use of water. Adv. Agron. 14: 223-264.

Wit, C. T. de, 1958. Transpiration and crop yields. Versl. landbouwk. Onderz. (Agric. Res. Rep.) 64.6, Pudoc, Wageningen.

Wit, C. T. de et al., 1978. Simulation of assimilation, respiration and transpiration of crops. Simulation Monographs, Pudoc, Wageningen. 